\title{
The virus in territory, between perceptions and
} measures

Sandra Pérez, Nicole Vernazza-Licht and Daniel Bley

\section{(2) OpenEdition \\ Journals}

Electronic version

URL: http://journals.openedition.org/rfst/888

DOI: $10.4000 /$ rfst.888

ISSN: 2492-3672

Publisher

Espaces et SOciétés (UMR 6590)

\section{Electronic reference}

Sandra Pérez, Nicole Vernazza-Licht and Daniel Bley, "The virus in territory, between perceptions and measures", Revue francophone sur la santé et les territoires [Online], Pandemic, crises and perspectives: territorial readings of Covid-19, Online since 11 March 2021, connection on 06 April 2021. URL: http:// journals.openedition.org/rfst/888 ; DOI: https://doi.org/10.4000/rfst.888

This text was automatically generated on 6 April 2021.

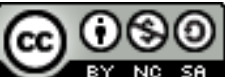

La Revue francophone sur la santé et les territoires est mise à disposition selon les termes de la Licence Creative Commons Attribution - Pas d'Utilisation Commerciale - Partage dans les Mêmes Conditions 4.0 International. 


\title{
The virus in territory, between perceptions and measures
}

\author{
Sandra Pérez, Nicole Vernazza-Licht and Daniel Bley
}

1 The handling of the health crisis resulting from the Covid19 pandemic has brought out the discrepancy between a centralizing State, in charge of its population's safety, that in an emergency health situation applies uniform measures to the entire country, and a population whose everyday experience in its territory doesn't necessarily reflect the same interpretation of the event and the logic behind the actions taken. We think that it might be interesting to consider the gap that may exist between the objective knowledge of phenomena likely to impact health, as it can be assessed by scientists or experts on a given space, and their representation by the inhabitants within their own living space in a viral pandemic situation.

2 What happens in fact when top down and bottom up meet? How do the assessment of space, safety-first principle, preventive measures, political decisions and population perception link up? This perception is generally based on representations of the disease and its etiology by non-experts, and results from their everyday-life experience in a given territorial space, whereas the assessment by experts resting on quantified data takes into account a dimension that may be considered as further away from the concerns of populations, more distant, colder. This is at times reinforced by the population's lack of knowledge about the methods used by scientists. This difference between assessment and perception of the same situation may generate feelings of lack of understanding, inhumanity, especially when the scientific or political line is intended to be more objective and becomes more alarmist than the one "expected" or experienced by the populations.

3 Furthermore, whereas public bodies and institutions are in charge of the community, the population often responds with individual strategies. Then the question arises for researchers of the diversity of behaviours at a time when they are looking for invariants - sufficiently reproducible elements in every places of the country.

4 We'll exemplify this approach with a case that seems to us to be one of the most emblematic and concerns measures adopted for dealing with the bodies of people who 
died during the epidemic. We will therefore discuss the application of decisions taken between measures and perceptions of risk, between national measures and local expectations.

5 In regard to the potential risk of virus transmission, we'll highlight the discrepancies between the advice of scientists and experts to limit interactions whilst preserving the burials' humanist dimensions (Public Health Authorities advice), the political decision of immediately placing the body in a coffin (decree of 2 April 2020), and the families' lack of understanding about not being able to come and practice the usual funerary rites; we'll therefore discuss the implementation of decisions taken between risk assessment and risk perception.

6 We will show how a whole set of decisions taken at the strictly national level has exacerbated identity processes between regions and the capital based on opposition rather than complementarity between measures and perceptions.

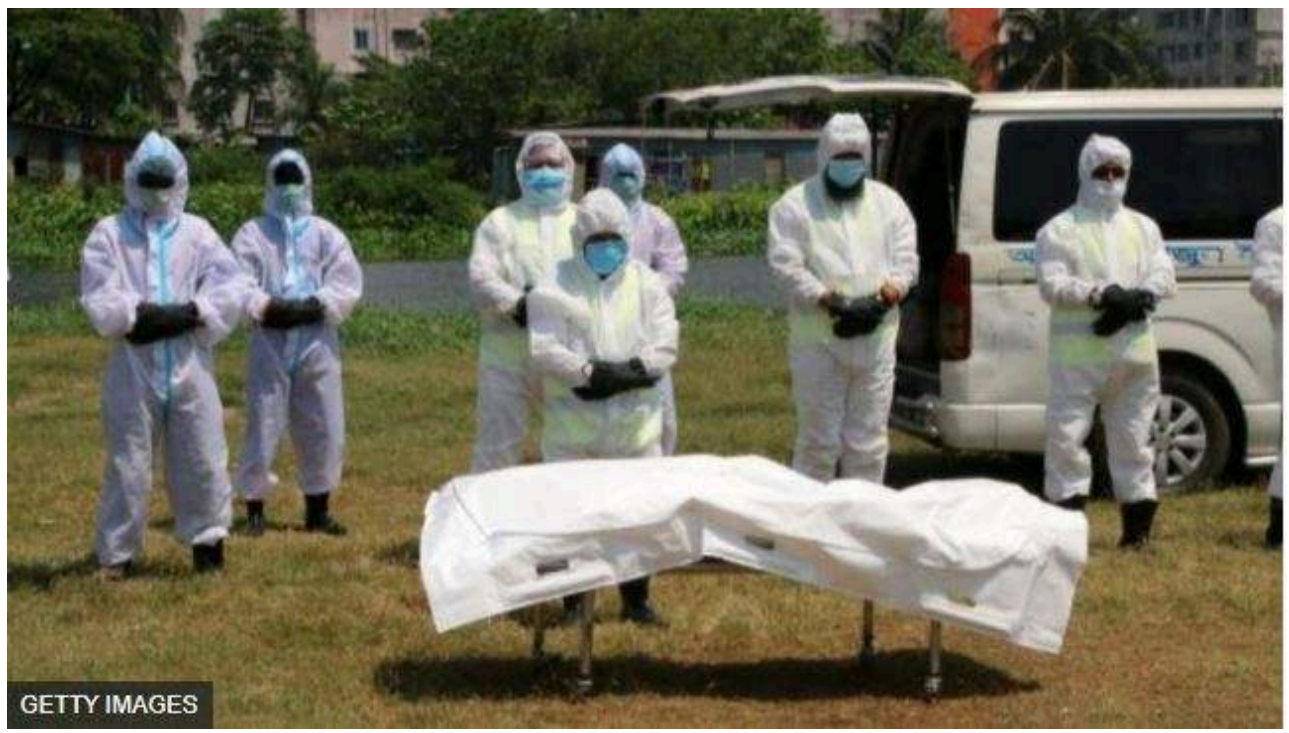

Source: BBC NEWS https://www.bbc.com/afrique/monde-52482383

INDEX

Mots-clés: Covid19, crisis, crisis management, precautionary principle, funeral rites

\section{AUTHORS}

\section{SANDRA PÉREZ}

Géographe de la santé, Université Côte d'Azur, UMR 7300, ESPACE, Nice, France

\section{NICOLE VERNAZZA-LICHT}

Anthropologue de la santé, UMR 7300, ESPACE, Nice, France 


\section{DANIEL BLEY}

Anthropologue biologiste, UMR 7300, ESPACE, Université d'Aix-Marseille, France 